\title{
Preparing personnel for a successful perception and assembly of the course of mathematics at the technical university
}

\section{Preparando o pessoal para uma percepção e montagem bem sucedida do curso de matemática na universidade técnica}

\section{Preparación del personal para una exitosa percepción y montaje del curso de matemáticas de la universidad técnica}

\author{
Lubov K. llyashenko ${ }^{1}$ (D), Dmitriy A. Belov ${ }^{1}$ (i)
}

${ }^{1}$ Industrial University of Tyumen, Tyumen, Russia.

Corresponding author:

Lubov K. Ilyashenko

Email: ilyshenkolk@mail.ru

Ilyashenko, L. K., \& Belov, D. A. (2021). Preparing personnel for a successful perception and assembly of the course of mathematics at the technical university. Revista Tempos e Espaços em Educação, 14(33), e16275.

http://dx.doi.org/10.20952/revtee.v14i33.16275

\begin{abstract}
Scientific and technological progress, digitalization of the economy, as well as all other spheres of human life, require qualified personnel. Technology, however, simplifies everyday life and gives students plenty of opportunities to enroll in college and not study at all. This study's main purpose is to investigate this paradox, instill in student's love, positive motivation to study mathematics, and encourage them to complete their learning tasks. The research method is a survey of first-year students of the fields of study "Oil and Gas Business" and "Technosphere Safety" of Tyumen Industrial University to identify the motivation for their study of the university mathematics program. It was found that at the moment, it is easier for students to find a calculating job than to do it themselves, that the perception of mathematics as a subject in the first year affects not only further academic performance in the university but also the entire professional life of a person. To solve the problem of motivating first-year students to study mathematics, as we have found out, it is possible if: use the "first type" of motivation, which consists in the fact that is influencing the student, cause certain internal motives prompting to study mathematics; take into account the age and individual characteristics of students and each new stream in general; identify the level of preparation of the school mathematics course.
\end{abstract}

Keywords: Mathematics. Motivation. Educational activities. Technical university.

\section{RESUMO}

O progresso científico e tecnológico, a digitalização da economia, assim como todas as outras esferas da vida humana, requerem pessoal qualificado. A tecnologia, no entanto, simplifica a vida 
cotidiana e dá aos alunos muitas oportunidades de se matricular na faculdade e não estudar. 0 objetivo principal deste estudo é investigar esse paradoxo, incutir no aluno o amor, uma motivação positiva para estudar matemática e incentivá-lo a concluir suas tarefas de aprendizagem. O método de pesquisa é uma pesquisa com alunos do primeiro ano das áreas de estudo "Negócios em Petróleo e Gás" e "Segurança da Tecnosfera" da Universidade Industrial de Tyumen para identificar a motivação para o estudo do programa de matemática da universidade. Verificou-se que, no momento, é mais fácil para os alunos encontrarem um trabalho de cálculo do que eles mesmos, que a percepção da matemática como disciplina no primeiro ano afeta não apenas o desempenho acadêmico posterior da universidade, mas também todo o profissional. vida de uma pessoa. Para resolver o problema de motivar os alunos do primeiro ano para o estudo da matemática, como vimos, é possível se: usar o "primeiro tipo" de motivação, que consiste no fato de estar influenciando o aluno, provocar certos motivos internos que o instigam estudar matemática; levar em consideração a idade e as características individuais dos alunos e de cada nova corrente em geral; identificar o nível de preparação do curso de matemática escolar.

Palavras-chave: Matemática. Motivação. Atividades educacionais. Universidade técnica.

\section{RESUMEN}

El progreso científico y tecnológico, la digitalización de la economía, así como todas las demás esferas de la vida humana, requieren de personal calificado. Sin embargo, la tecnología simplifica la vida cotidiana y brinda a los estudiantes muchas oportunidades para inscribirse en la universidad y no estudiar en absoluto. El objetivo principal de este estudio es investigar esta paradoja, inculcar en el amor de los estudiantes una motivación positiva para estudiar matemáticas y alentarlos a completar sus tareas de aprendizaje. El método de investigación es una encuesta a estudiantes de primer año de los campos de estudio "Negocio de petróleo y gas" y "Seguridad de la tecnosfera" de la Universidad Industrial de Tyumen para identificar la motivación para su estudio del programa universitario de matemáticas. Se encontró que en este momento, es más fácil para los estudiantes encontrar un trabajo de cálculo que hacerlo ellos mismos, que la percepción de la matemática como asignatura en el primer año afecta no solo el desempeño académico en la universidad sino también a todo el profesional. vida de una persona. Para resolver el problema de motivar a los estudiantes de primer año a estudiar matemáticas, como hemos visto, es posible si: se utiliza el "primer tipo" de motivación, que consiste en el hecho de que está influyendo en el estudiante, provocan ciertos motivos internos que incitan estudiar matemáticas; tener en cuenta la edad y las características individuales de los estudiantes y cada nueva corriente en general; Identificar el nivel de preparación del curso de matemática escolar.

Palabras clave: Matemáticas. Motivación. Actividades educativas. Técnico universitario.

\section{INTRODUCTION}

The digital industry, which currently permeates all spheres of human life, requires qualified personnel. However, technology not only simplifies our daily lives, but also gives students plenty of opportunities to not learn at all. The course of higher mathematics is one of the foundational courses for higher technical educational institutions. And the first, providing entry into the educational process, the formation of scientific thinking and attitude to the profession, are mathematical disciplines that are difficult for most students to master. The fundamental question is that how we can overcome this paradox, instill in students a love of mathematics and encourage them to complete their learning tasks themselves (Ariffin et al., 2021).

Leading educators, psychologists and practicing mathematicians have already tried to find an answer to this question. In this article we turn to the domestic experience of A.K. Markova. (Markova et al., 1990), Ilyina E.P. (Ilyin, 2013), J. Piaget (Piaget, 1967), Demidovich B.P. (Demidovich 1961) and his colleagues and abroad, including R. Gouia, S. Gann (Gouia \& Gunn, 2016), Atuahene 
and Russell (2016), Pemantle (2011), Zachry Rutschow (2019), Report of the workshop held at the MAA Carriage House Washington (2016), The National Academies of Sciences, Engineering, and Medicine (2019), Benken, Ramirez, Li, and Wetendorf (2018), Franklin (2016), Reusser (2000). In search of a solution, the pedagogical community has now formulated the problems of motivation, the correspondence of the course to professional needs, the quality of the available teaching material, as well as the availability of the skill of independent work. This article provides a brief pedagogical analysis of studies aimed at encouraging positive motivation to study mathematics in freshmen.

Students of universities begin to study a mathematics course from the first days of their studies. Mathematics is the most important component of a student's fundamental training, a "universal technical language" and contributes to the development of thinking. In the process of training a specialist, a mathematician also performs a disciplining methodological function. Despite this, students perceive mathematics as an abstract science, divorced from reality. This is due to the fact that at the moment of studying it, students do not have special knowledge that would allow them to show the connection between mathematics and their future profession and do not understand what knowledge they will really need. Constant workload and lack of time complicate the development of a student's culture of independent mathematical thinking, which, in turn, during the first semester makes it difficult to reveal the great importance of mathematics as a means of solving applied professional problems (Singh et al., 2020).

Thus, the university and the teacher are faced with the task of influencing the student, that is, stimulating positive motivation in him in such a way that yesterday's schoolchild will have a desire to study at a technical university and to scientific activity in general.

This article allows you to take a fresh look at the motivation and motivation of today's students.

\section{METHODOLOGY}

The research method is a questionnaire survey of first-year students of the specialties of the fields of study "Oil and Gas Business" and "Technosphere Safety" of Tyumen Industrial University to identify the motivation for their study of the university mathematics program. The number of students surveyed was 93.7 people refused to participate in the study.

The survey was carried out in the form of a Google form to speed up information collection. It was also found that people are reluctant to agree to an electronic survey as opposed to an oral one: after seven refused to fill out the questionnaire without explaining the reasons or referring to the fact that there was no time, it was decided to continue the survey only orally.

Below is the questionnaire "Attitude of first-year students to the study of mathematics at a technical university" (Table 1). 
Table 1. Application form The Attitude of First-Year Students to Studying Mathematics at a Technical University

\begin{tabular}{|c|c|c|}
\hline № & Question title & Answer options \\
\hline 1. & $\begin{array}{l}\text { Are you studying in the first year of the direction of study "Oil } \\
\text { and Gas Business" or "Technosphere Safety"? }\end{array}$ & $\begin{array}{ll}\text { a) } & \text { Yes } \\
\text { b) } & \text { No }\end{array}$ \\
\hline 2. & What motivates you to study mathematics in college? & $\begin{array}{l}\text { a) The need to pass the exam } \\
\text { b) Striving to become a good } \\
\text { professional } \\
\text { c) Love for mathematics as a science }\end{array}$ \\
\hline & & $\begin{array}{l}\text { a) Difficult, one of the most } \\
\text { difficult subjects to understand }\end{array}$ \\
\hline 3. & How difficult is it for you to study mathematics? & $\begin{array}{l}\text { b) Not difficult, but not easy } \\
\text { c) } \quad \text { Easy, I love math }\end{array}$ \\
\hline 4. & $\begin{array}{l}\text { Do you think the higher mathematics course's knowledge will } \\
\text { be useful to you in your future profession? }\end{array}$ & $\begin{array}{l}\text { Yes, they will definitely come in } \\
\text { Maybe } \\
\text { No, not useful }\end{array}$ \\
\hline 5. & $\begin{array}{l}\text { How often do you use Internet resources to do any math } \\
\text { work? }\end{array}$ & $\begin{array}{l}\text { Always } \\
\text { Often } \\
\text { Rarely, in the most difficult } \\
\text { Never }\end{array}$ \\
\hline
\end{tabular}
form.

Consent to the processing of data was given automatically as a result of filling in a Google

According to the results of our research, the following main sub-points can be distinguished:

- $\quad 93 \%$ consider math to be one of the most difficult subjects.

- $60 \%$ believe that university mathematics will not be useful to them in their profession.

- $64 \%$ study math to pass the exam and forget.

- Less than $10 \%$ like mathematics as a science.

- More than $50 \%$ of students use Internet resources to do math work.

Similar results were obtained by our compatriots as a result of the study of part-time students of the Siberian State Aerospace University in 2016-2017 admission years (Balashova \& Manushkina, 2011). In contrast to the research of colleagues, this survey involved students from two different areas of study: "Oil and Gas Business" and "Technosphere Safety".

It was found that some students are reluctant to participate in the survey, especially in electronic form. Investigating questions of motivation, we came to the conclusion that at the stage of the survey, students also need to be motivated. The guys are in dire need of motivation and motivation to perform any kind of activity, even as simple as answering a few questions of the questionnaire. The full percentage of the results during the survey are shown in Table 2. 
Table 2. Results of the survey

\begin{tabular}{|c|c|c|c|}
\hline № & Question title & Answer options & Percentage \\
\hline \multirow[t]{2}{*}{1.} & \multirow{2}{*}{$\begin{array}{l}\text { Are you studying in the first year of the } \\
\text { direction of study "Oil and Gas Business" or } \\
\text { "Technosphere Safety"? }\end{array}$} & a) Yes & $100 \%$ \\
\hline & & b) No & $0 \%$ \\
\hline \multirow{3}{*}{2.} & \multirow{3}{*}{$\begin{array}{l}\text { What motivates you to study mathematics in } \\
\text { college? }\end{array}$} & a) The need to pass the exam & $64 \%$ \\
\hline & & $\begin{array}{l}\text { b) Striving to become a good } \\
\text { professional }\end{array}$ & $22 \%$ \\
\hline & & $\begin{array}{l}\text { c) Love for mathematics as a } \\
\text { science }\end{array}$ & $8 \%$ \\
\hline \multirow{3}{*}{3.} & \multirow{3}{*}{$\begin{array}{l}\text { How difficult is it for you to study } \\
\text { mathematics? }\end{array}$} & $\begin{array}{l}\text { a) Difficult, one of the most } \\
\text { difficult subjects to understand }\end{array}$ & $93 \%$ \\
\hline & & b) Not difficult, but not easy & $5 \%$ \\
\hline & & c) Easy, I love math & $2 \%$ \\
\hline \multirow[t]{3}{*}{4.} & \multirow{3}{*}{$\begin{array}{l}\text { Do you think the knowledge gained on the } \\
\text { higher mathematics course will be useful to } \\
\text { you in your future profession? }\end{array}$} & $\begin{array}{l}\text { a) Yes, they will definitely come in } \\
\text { handy }\end{array}$ & $40 \%$ \\
\hline & & b) Maybe & $25 \%$ \\
\hline & & c) No, not useful & $35 \%$ \\
\hline \multirow{4}{*}{5.} & \multirow{4}{*}{$\begin{array}{l}\text { How often do you use Internet resources to do } \\
\text { any math work? }\end{array}$} & a) Always & $18 \%$ \\
\hline & & b) Often & $46 \%$ \\
\hline & & $\begin{array}{l}\text { c) Rarely, in the most difficult } \\
\text { cases }\end{array}$ & $10 \%$ \\
\hline & & d) Never & $26 \%$ \\
\hline
\end{tabular}

The course of mathematics is one of the fundamental for higher technical educational institutions and the first, providing entry into the educational process, the formation of scientific thinking and attitude to the profession, mathematical disciplines are difficult for most students to master. More than half of the students believe that mathematics will not be useful to them, and more than half also study it just to pass the exam.

The problem of motivation - touches upon the reasons for success or failure in achieving the required level of mathematical competence by students and the essence of motivation and motive. This is one of the main problems in pedagogy and psychology. On that score, there are many different opinions of specialists. However, a single position regarding the essence of motive and motivation has not been identified.

Each of the researchers sees the essence of the motive differently. Some see motive as the goal of the activity, a need, or a stable personality attribute. Citing the creation of Ilyin E.P. : "The solution to the question of the essence of the motive as the basis and stimulus of human activity is possible only by combining existing views in a single and consistent concept" (Ilyin, 2013). At the present time, the idea is increasingly clear that the nature of behavior and activity is determined not by isolated factors but by their aggregate, where each of them, in the integral process of determining human behavior, performs its own specific functions. Thus, it is more legitimate to consider the motive as a complex psychological formation.

Revealing the motives of educational activity, Markova A.K. notes that the stimulus of educational activity is such a system of motives, which organically includes cognitive needs, goals, interests, aspirations, ideals, and motivational attitudes, which give it a dynamic and directed character, are included in the structure and determine its content-semantic features (Markova et al., 1990).

Such a set of motives forms learning motivation, which, in turn, is characterized by both stability and dynamism. 
The function of motives. When students study mathematics, their motives result as follows:

1. The development of motives for the study of mathematics contributes to the qualitative development of other mathematical disciplines, the language of scientific communication, as well as the formation of scientific thinking in general.

2. The desire for a deeper knowledge of complex mathematical disciplines for most students contributes to the general intellectual development of students and forms attitudes towards the cognitive activity.

3. The orientation and stability of the considered motives contribute to the formation of the student as a person who knows how to learn, who knows what he is studying for, and the desire to become a competent specialist, successful in his field.

4. Motivation for deep mastering of the foundations of mathematics contributes in the future to a deeper understanding of special disciplines. As a result, the students who successfully participated in mathematics olympiads and competitions in their junior years had a high rating in the exact sciences, often in senior years and after graduating from the university, to achieve success in research activities (Gorodilova, 2018; Pidluzny et al., 2019).

Why motivation or setting goals correctly? Because according to research, more than half of students are externally motivated and study mathematics in order to pass an exam and get a diploma instead of becoming a strong specialist in their field thanks to mathematics. Moreover, only forty percent of first-year students believe that deep knowledge of the course of higher mathematics is really necessary for further professional growth. This means that everyone else believes that they do not need it. Moreover, ninety-three percent put mathematics in the top three most difficult subjects. And complexity, along with a lack of purpose, further reduces student motivation. At the moment, a very small part remains motivated - less than ten percent (Gorodilova, 2018). These students study mathematics because they are interested in mathematics as a science.

A study conducted by colleagues shows that at the moment, the motivation for studying a mathematics course is formal among students and most often is not associated with future professional growth; this seems to be the case. This also determines that seventy-four percent of the respondents resort to outside help in completing educational assignments.

Motivation determines efficiency. Motivation, as the driving force of human behavior and activity, is the leading link in the structure of the personality and determines the effectiveness of any activity of the subject, including activities aimed at obtaining an education. Thus, the presence of actual motivation of the academic discipline is a necessary condition for the student's productive learning. To form a high motivation for education, a student must have a formed image of the future profession, which will give a personal meaning to the educational process. Understanding how the acquired knowledge affects the change in his professional situation and how it will help solve professional problems will motivate the student to study the material in depth. It was rightly noted by E.P. Ilyin that "a goal will stimulate a person only when its achievement has some meaning for him. Senseless work not only reduces the strength of the motive but also degrades the dignity of a person" (Noskov \& Shershneva, 2006; Koroleva, 2020).

Motivation, as the driving force of human behavior and activity, is the leading link in the personality structure and determines the effectiveness of any activity of the subject, including activities aimed at obtaining an education. Thus, the presence of an actual motivation for studying an academic discipline is a necessary condition for a student's productive learning. Suppose we consider the problem of the formation of motivation for the study of mathematical disciplines by a student of a technical university. In that case, the development of motives associated with the content of the teaching is facilitated by the teacher's activities aimed at showing, on the one hand, the beauty of mathematical statements, proofs, reasoning, on the other hand, to demonstrate the need for a student to master quite difficult theory for obtaining the chosen profession. In this case, the use of professionally-oriented tasks and other competence-based approaches to teaching 
mathematics in the educational process is of particular relevance (Starodubtseva, 2014). It should be noted that the focus of mathematical knowledge on the practical application does not exclude or replace the need to understand the foundations of mathematical theory. The educational format's conciseness often does not allow paying much attention to the theoretical foundations of the academic discipline, rigorous mathematical proofs, but without them, understanding the subject of study is impossible. Therefore, when developing a methodology for motivating students, this must be taken into account.

For a long time, the professional community has been exploring the possibilities of successfully motivating students to develop their learning opportunities to achieve results in educational activities, namely in the study of mathematics and mathematical disciplines.

Motivation is the process of influencing a student in order to induce him to certain actions by inducing the necessary motives in him (Gorodilova, 2018). Motivation is the foundation of human governance. And motivation, as mentioned above, is one of the main factors for successful learning. The effectiveness of motivation largely depends on the individual and the situational characteristics (factors). Every teacher wants his students to study well and willingly. Not only heads of universities are interested in this, but also enterprises.

The specificity of the types and the effectiveness of motivation differ at different stages of training. But at the initial stages, we often meet with the fact that some students have not yet developed a need for knowledge, an interest in learning has not matured. In the first year, students are just learning to learn; they form their attitude to their future profession. And only after that, with or without desire, they lay the foundation of their theoretical base.

The professional community shares the opinion that the true source of a person's motivation is not anywhere but in himself (Starodubtseva, 2014). Therefore, it is so necessary that he himself would want to do something and do it.

So, as mentioned above, motivation is the process of influencing a student in order to induce certain motives in him. Motivation is usually of two types. For first-year students, the first type is more applicable - based on the needs experienced by a person and causing internal motivation. Such motives induce the student to take actions that often lead to the desired result.

Different motivations apply to different types of students. There are three types of educational motivation. The first one can be defined as a high level of educational motivation: such students already have a cognitive motive; they have formed a desire to fulfill the presented requirements well. As a rule, they are responsible and conscientious, and they care about the grades they receive. We define the second type as a good level of educational motivation: students successfully cope with educational activities, perform tasks as "good" or "satisfactory" while calmly treating the received grades. This level is the average norm. The third type is simply a neutral attitude towards the university. The university attracts these students through extracurricular activities. They are sociable. Communicate easily with fellow students and teachers. The level of cognitive motives of these students is low; they experience difficulties in learning activities and have a "negative" attitude towards mathematics (Bakshaeva \& Verbitsky 2017).

Therefore, unambiguously, education at a university should be more subject-oriented and motivated.

It should be noted that "adolescence is a stage of special cognitive development, when memory, logical thinking, and speech (monologue and writing) are improved" - J. Piaget (Piaget, 1967).

With regard to the duration of age-related development, scientists note that modern young men and women are characterized by an increase in the rate of somatic development and an earlier onset of skeletal ossification, an acceleration of the timing of puberty than before, which, unfortunately, is not accompanied by an equally rapid rate of psychological development. Often, students feel like they are adults, but they are not. 
At the time of graduation, future students have already mastered certain scientific concepts; it can be considered that logical and theoretical thinking has been formed. Therefore, in the first year, students can already conduct theoretical reasoning on certain topics, are able to draw general conclusions based on particular premises, and, conversely, derive particular ones on the basis of general premises (Sokolova, 2008).

Significant growth of consciousness and self-awareness of a person, an expansion of knowledge about himself, about the world around him, and about society occurs at the age of 1718 , during the same period he entered a university. At this age, such a necessary ability in studying at a university is fixed, such as self-control and planning of activities, and communicative abilities develop. The educational activity is gradually being modified into educational and professional. Therefore, it is so important in this fruitful period for learning to convey to students the importance of mastering mathematics.

So, a first-year student has the following psychological characteristics: the foundations of theoretical thinking and the skills of mental actions are formed, there is a need to take the position of an adult - a member of society, value orientations, and moral attitudes are determined, individuality is formed as a result of evaluating one's abilities and interests. The listed individual psychological characteristics significantly affect the motivation of educational activity.

For the construction of the educational process, the level of school mathematical training is of great importance. The first semester of study at the university is a difficult adaptation period for yesterday's school graduates. The habit of learning according to a regulated school scheme is very strong at the initial stage. If the teacher tries, as an illustration of the material being studied, to give a specific task of professional content (calculation of structures, calculation of plant emissions, an economic model of the market.), To formulate its mathematical model, he runs into a wall of misunderstanding, since students are not yet accustomed to independent thinking and own the concepts of the future profession's processes.

It turns out, on the one hand, the teacher needs to explain how the knowledge acquired at the university will be useful to him in the future. The teacher must be able to prove to students that his subject will really be useful in his future activities, on the other hand, to explain the material in an accessible language (Plotnikova 2002). Also, do it in a short time period. However, this is not easy - for former schoolchildren to master a large amount of new material.

Having many years of experience working with junior students, the professional community has determined that students' age and individual characteristics in each set are not the same, and the educational material is perceived by one stream of students differently from the previous one. Therefore, the techniques and methods of motivating students to study mathematical disciplines for each new course should also differ from the previous ones (Gorodilova, 2018).

Each new stream of students has its own characteristics, different from those possessed by the previous set's students. Therefore, it is necessary to take into account the age and individual characteristics of students.

Based on the foregoing, for the organization of students' successful motivation, techniques and methods should be used in accordance with the age and individual characteristics of students. We have determined: in the first semester, the organization of motivation should be focused on cognitive motives, on optimizing interest in studying the material, in solving these tasks, in understanding the significance of learning. When teaching, a group solution of tasks can be used to alter different types of activity (written and oral, easy and difficult). Questions should be formulated so that students can compare, compare, and challenge another decision; counterexamples are given to refute the mistakes made so that the children learn to prove their case.

If students need to focus on cognitive and research motives, it is worth using the experience of "problematic" learning (search, experimental, explanatory and illustrative methods). So when teaching new sections of mathematics, students should be kept in constant activity throughout the 
lesson. By asking leading questions, we will be able to control students' thinking process, leading to the "discovery" of new knowledge, and such questions are possible that allow students to put forward and test hypotheses.

In the second and third semesters, other techniques and methods of motivation are used. Students have become more mature, have acquired experience of studying at a university, the prestige of knowledge has increased, self-esteem has become higher. Students learned to quickly process information, highlight and consider approaches and methods of solving tasks and make rational decisions. In addition, observations showed that students' motivation for learning changed. The learning situation contains many opportunities for achieving high results, which means that it can be assumed that students with a high need for achievements will experience greater satisfaction from learning, invest more effort in the learning process, which will lead to higher learning outcomes (more high student achievement).

Summing up the above, we note that the research of the process of successfully motivating students to learn, to achieve good results in educational, later in scientific activities, should be carried out taking into account many features. Students' learning activity motivation also changes over time, so the techniques and methods of motivation need to be adjusted.

The problem of motivation in a distance learning format. The problem of motivation becomes especially acute in the case of distance learning, based largely on independent work, which requires a high level of self-organization and self-control from the student, which can only be achieved in the case of the high motivation of educational activity (Plotnikova 2002).

To motivate you to study mathematics in distance learning, you must:

1. Availability of high-quality educational and methodological support available to the student and helping him in the development of mathematics and necessary for further education.

2. For students to better understand mathematics at the university, a system of preuniversity training is needed, for example, preparatory courses that help an applicant enter a technical university to remember the course of profile school mathematics better.

3. Formation of a benevolent environment and a positive attitude, allowing students to hope that the difficulties arising with mathematics are surmountable provided the student's purposeful learning activity.

4. Reasonable combination in the lecture material on mathematics rigor of presentation, clarity, accessibility.

5. Balance of tests, the content of which should be complete enough to cover the main types of problems that a student must learn to solve, but not too difficult so as not to push the majority of students to order the solution of tests in the paid educational services market.

6. Use modern educational technologies: discussion forms of practical training, computer tools, elements of test and rating technologies. All this brings elements of the game into the educational process.

7. Social motives are also important for students. For working students and children, success as a student is not indifferent, and adults are just as happy about good grades and achievements in overcoming learning difficulties as children.

8. An important motivating factor for a student's striving not only for a diploma but also for quality education is the confidence that he will be in demand in the future as a specialist and will be able to apply the acquired knowledge in practice.

\section{CONCLUSIONS}

Understanding the high importance of the motive for learning for a successful study led to the formulation of the educational process's principle of motivational support. Which says that "during training in a higher educational institution, the "strength" of the motive for learning and mastering the chosen specialty decreases" (Sokolova, 2008). To really get involved in work, the tasks 
set before them in the course of their educational activities must be clear and internally accepted by them to become meaningful for the student. Learning motivation is determined by a number of factors characteristic of this activity: first of all, the organization of the educational process; an educational institution where educational activities are carried out; age and individual characteristics of the student (age, intellectual development, abilities, level of aspirations, selfesteem, interaction with comrades); subjective characteristics of the teacher and the system of his attitude to the student and to his work; as well as the specifics of the academic discipline or subject, in our consideration - mathematics.

The success of students' teaching largely depends on the level of development of their cognitive abilities - perception, thinking, imagination, memory, and the level of development of cognitive abilities is not only the result of past years. The system of educational influence has a decisive influence on development at any age. Therefore, in terms of content, forms, and methods, motivation should be dynamic, built, taking into account the stages of age development.

The pedagogical analysis showed that for the organization of the educational process, involving a productive impact on the student, to motivate the successful study of mathematics, it will be effective if you use the "first type" of motivation, which consists in the fact that influencing the student, cause certain internal motives that induce the study of mathematics, take into account the age and individual characteristics of students, identify the level of preparation of the school mathematics course.

Authors' Contributions: Lubov K. Ilyashenko: conception and design, acquisition of data, analysis and interpretation of data, drafting the article, critical review of important intellectual content. Dmitriy A. Belov: conception and design, acquisition of data, analysis and interpretation of data, drafting the article, critical review of important intellectual content. All authors have read and approved the final version of the manuscript.

Ethics Approval: Not applicable.

Acknowledgments: Not applicable.

\section{REFERENCES}

Ariffin, A. H., Wahid, R. A., Sulaiman, S., Mansor, M., \& Abd Wahab, M. H. (2021). The Development of an e-Workload Distribution System: A Focus on the Fair Distribution of Teaching Workloads of Lecturers. Asian Journal of University Education, 16(4), 31-43.

Atuahene, F., \& Russell, T. A. (2016). Mathematics readiness of first-year university students. Journal of Developmental Education, 12-32.

Bakshaeva, N., Verbitsky, A. (2017). Psychology of student motivation. Litres.

Balashova, O. Yu., Manushkina, M. M. (2011). The dynamics of the formation of motivation for the study of mathematics among applicants and students of a technical university. Bulletin of the Krasnoyarsk State Pedagogical University. V.P. Astafiev, 1.

Benken, B. M., Ramirez, J., Li, X., \& Wetendorf, S. (2015). Developmental mathematics success: Impact of students' knowledge and attitudes. Journal of developmental education, 14-31.

Demidovich, B.P. (1966). Tasks and exercises in mathematical analysis for technical colleges. Ripol Classic.

Franklin, B. (2016). Understanding the success and failure of African American first time developmental mathematics students: A racialized perspective (Doctoral dissertation, Morgan State University).

Gorodilova, M.A. (2018). Features of Motivating Junior Courses Students to Study Mathematical Disciplines. In SocioPedagogical Technologies in Socialization of the Future Professional (pp. 18-23).

Gouia, R., \& Gunn, C. (2016). Making mathematics meaningful for freshmen students: investigating students' preferences of pre-class videos. Research and practice in technology enhanced learning, 11(1), 2.

Ilyin, E. P. (2013). Motivation and motives. Publishing house "Peter". 
Koroleva, O.A. (2020). Features of the motivation of students in distance learning. In Pedagogical Forum (pp. 215-217).

Markova, A.K., Matis T.A., Orlov, A.B. (1990). Formation of motivation for learning (pp. 192-192). Joint-stock Company" Publishing house" Education ".

National Academies of Sciences, Engineering, and Medicine. (2019). Increasing Student Success in Developmental Mathematics: Proceedings of a Workshop. National Academies Press.

Noskov, M. V., Shershneva, V. A. (2006). The quality of mathematical education of an engineer: tradition and innovation. Pedagogy, 6, 35-42.

Pemantle, R. (2011). What You (Should) Get out of Freshman Calculus Amy Nelson, Jessica Santina (2020) The 20 Most Common College Freshman Mistakes.

Piaget, J. (1967). Selected psychological works / Jean Piaget. M.: Education.

Pidluzny, J., Urban, N., \& Kempson, L. (2019). What Will They Learn? A Survey of Core Requirements at Our Nation's Colleges and Universities, 2019-2020. American Council of Trustees and Alumni.

Plotnikova, E.G. (2002). Technology of a profile approach to teaching mathematics in a military engineering university.

Reusser, K. (2000). Success and failure in school mathematics: effects of instruction and school environment. European Child \& Adolescent Psychiatry, 9(2), S17-S26.

Singh, P., Yusoff, N. M., \& Hoon, T. S. (2020). Content Analysis of Primary School Mathematics Textbooks and Its Relationship with Pupils Achievement. Asian Journal of University Education, 16(2), 15-25.

Sokolova, M. V. (2008). Sociological research of motivation for obtaining higher education. Bulletin of the Nizhny Novgorod University. N.I. Lobachevsky, 5.

Starodubtseva, V.K. (2014). Motivating students to learn. Modern problems of science and education, 6, $432-432$.

Zachry Rutschow, E. (2019). The National Academies of Sciences, Engineering, and Medicine Workshop on Understanding Success and Failure of Students in Developmental Mathematics: Developmental Mathematics Reforms.

Received: 12 May 2021 | Accepted: 2 August 2021 | Published: 25 August 2021

This is an Open Access article distributed under the terms of the Creative Commons Attribution License, which permits unrestricted use, distribution, and reproduction in any medium, provided the original work is properly cited. 